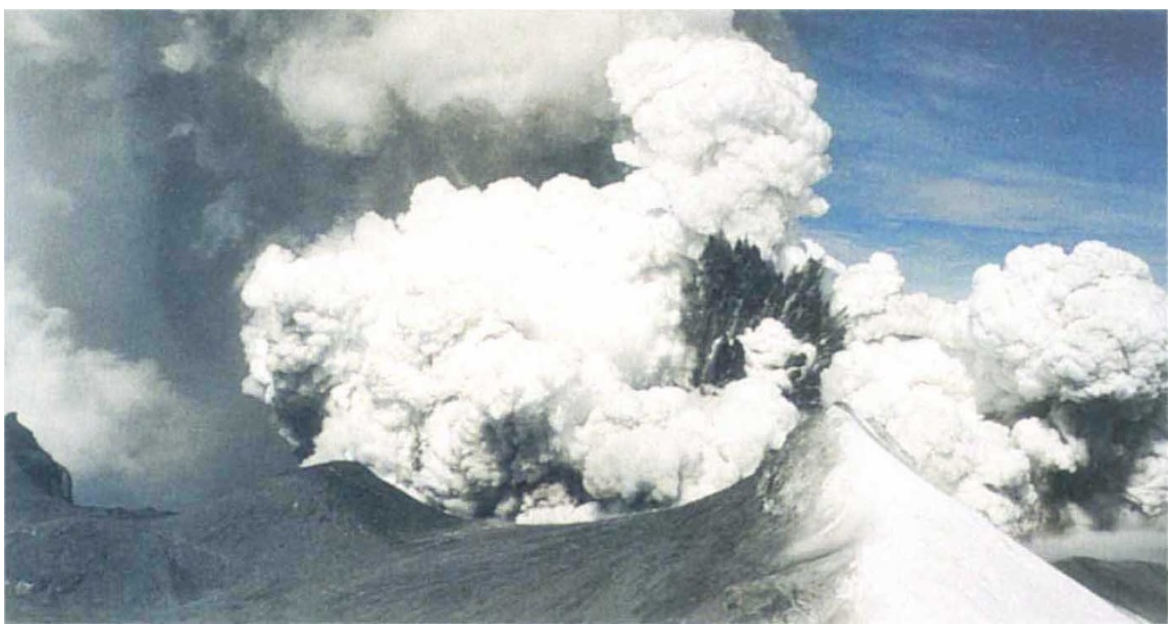

Eruptive activity on Mount Ruapehu. Photography by I. A. Nairn, Institute of Geological and Nuclear Sciences.

have problems in reconciling all the geochemical characteristics of single rhyolite samples with those of any credible crustal source material. Proponents of crystallization models have equally knotty problems in explaining why their chosen process should have gone on to produce dominantly rhyolite, instead of andesite or dacite, and where the large volumes of crystalline material (complementary to the erupted rhyolite) are to be found. At present, combination (AFC) models are preferred $^{6,7}$, in which the mantle-derived basalts melt and incorporate a limited amount of crustal material (up to 25 per cent by mass), then the resulting andesitic magma evolves to rhyolite by crystallization. This combination approach neatly inherits and suffers from the same problems as both of the contributing mechanisms, and still fails to explain why rhyolite volcanism should be so geographically confined in an area so closely coincident with the area of high geothermal heat flux.

The central TVZ is unusual in other respects. The Yellowstone system (like many other rhyolitic systems in the western United States) shows cycles of activity that revolve around huge caldera-forming eruptions, on time scales of $10^{5}-10^{6}$ years, which are inferred to tap long-lived magma chambers of enormous size ${ }^{8}$. In contrast, the TVZ has more frequent but moderate-sized caldera-forming events, on average every 40,000-50,000 years'. This higher eruption frequency is now being interpreted ${ }^{9}$ to reflect the thinned and intensively faulted nature of the crust below the central TVZ (which is rifting at rates of 7-18 $\mathrm{mm} \mathrm{yr}^{-1}$; ref.10), which does not permit the build-up of huge, longlived magma chambers. For example, at Taupo volcano itself, rapid step-wise changes in composition of rhyolite eruptives over the past 20,000 years suggest that a large magma chamber may not even be present below the volcano for much of the time ${ }^{11}$
This leads to some intriguing new possibilities. First, if rifting is important in controlling rapid release of magma stored in the crust, does this mean that timings of eruptions at individual volcanoes in the TVZ may reflect tectonic, not magmatic, controls $^{12}$ ? Second, if the high frequency of TVZ eruptions results in 'snapshots' of the magmatic processes at intervals of decades to a few thousand years, much shorter than is considered the norm ${ }^{8}$, does this permit us to disentangle the processes forming the rhyolite from those modifying the rhyolite as it is held in the crust before eruption?

The central TVZ has been known for over 130 years to be an exceptionally vigorous area of rhyolitic volcanism ${ }^{13}$. Although in the mean time an impressive body of observations has been accumulated on the TVZ, the search for the causes of its unique features look likely to exercise geologists for some years to come.

Colin J. N. Wilson is at the Wairakei Research Centre of the Institute of Geological and Nuclear Sciences, Private Bag 2000, Taupo, New Zealand.

1. Simmons, S. F. \& Weaver, S. D. (eds) J. Volcanol. geotherm. Res. 68, 1-238 (1995).

2. Hochstein, M. P. J. Volcanol. geotherm. Res. $\mathbf{6 8}$, 117-151 (1995).

3. Wilson, C. J. N. et al. J. Volcanol. geotherm. Res. 68 1-28 (1995).

4. Bibby, H. M., Caldwell, T. G., Davey, F. J. \& Webb, T. H. J. Volcanol. geotherm. Res. 68, 29-57 (1995).

5. Smith, R. B. \& Braile, L. W. Geol. Sun. Wyoming Mem 5, 694-754 (1993)

5, 694-754 (1993).
6. McCulloch, M. T., Kyser, T. K., Woodhead, J. \& Kinsley, L. Contrib. Mineral. Petrol. 115, 303-312 (1994). . Graham, I. J., Cole, J. W., Briggs, R. M., Gamble, J. A. \& Smith, I. E. M. J. Volcanol. geotherm. Res. 68, 59-87 (1995).

8. Smith, R. L. Geol. Soc. Am. Spec. Pap. 180, 5-27

(1979).

9. Houghton, B. F. et al. Geology 23, 13-16 (1995)

10. Darby, D. J. \& Williams, R. O. N. Z. J. Geol. Geophys. 34, 127-136 (1991)

11. Sutton, A. N., Blake, S. \& Wilson, C. J. N. J. Volcanol. geotherm. Res. 68, 153-175 (1995).

12. Wilson, C. J. N. Phil. Trans. R. Soc. Lond. A343, 205-306 (1993).

13. von Hochstetter, F. Geologie von Neu Seeland (1864; Engl. transl. Fleming, C.A., Government Printer, Wellington. New Zealand, 1959).

\section{Deep treasure}

HEAVY metals play a crucial part in technology. Gold for circuit boards, platinum for catalysts and crucibles, tungsten for lamp filaments and uranium for nuclear power, all are rare and expensive. They are also all about twenty times as dense as water, seven times as dense as rock. And this, says Daedalus, is why they are rare. Geologically, our Earth is a viscous fluid; over its billion-year history these heavy metals have almost completely sunk down into its core.

The heavy metals do occur in sea water, though in tiny concentrations: about 1 part in $10^{11}$ for gold, for example. But gold and its compounds are much denser than sea water. They will sink in the oceans just as they do in the Earth. Their concentrations should rise exponentially with depth, like a solution of high-molecular-weight protein in an ultracentrifuge. Daedalus estimates that $10 \mathrm{~km}$ down, there should be at least a thousand times as much gold as at the surface, and maybe many millions of times, depending on the molecular weight of the dissolved gold compound. Abyssal water may well be richer than the gram per tonne of typical goldmine ore.

So DREADCO oceanographers are fitting a drilling barge with ten kilometres of polypropylene pipe, to reach down into the deepest trenches of the ocean and pump up the water. The pipe will be weighted to exactly neutral buoyancy so that it will neither load the vessel down nor be stressed by its own weight. As the water comes aboard, it will be chemically processed to extract the heavy metals: not only gold, but platinum, palladium, rhodium and many others. The operation should be hugely profitable.

Mercury, the only liquid heavy metal, may be a special case. It often occurs 'native' as the pure liquid. Over geological time this too should have found its own level and sunk to the bottom of the ocean deeps. Huge pools of mercury must lurk under the ooze of the deep-sea trenches, waiting to be pumped up. Furthermore, they should have amalgamated and absorbed a rich haul of the other bottomdwelling heavy metals. Sadly, no pump could suck up a ten-kilometre column of mercury. But Daedalus recalls that grinding mercury with a fat can divide it stably into tiny fat-coated globules. Mercurial ointments for syphilis were made this way, as was the famous, and famously hazardous, 'Blue Pill' purgative. The DREADCO team are designing a deep-sea ultrasonic agitator fed with lard, to break the mercury into an emulsion of such globules. The upward rush of pumped water should then entrain them and waft them effortlessly to the surface.

David Jones 